\title{
Research on Metal Supervision and Inspection Standards for Gas-steam Combined Cycle Units
}

\author{
SHI Yan ${ }^{*}$, XIANG Wenguo, CHEN Shiyi \\ Southeast University, Nanjing 210096, China
}

\begin{abstract}
Domestic gas-steam combined cycle units start and stop frequently, and the load changes greatly, which accelerate the expansion of defects, such as fatigue, cracks, and organizational deterioration of metal components. In view of the problems caused by the material selection characteristics of gas-steam combined cycle units and the daily shutdown mode, several common typical cases of gas-steam combined cycle units are analyzed, such as compressor blade fatigue fracture, main steam combined valve body fatigue cracks, pipeline and pressure vessel weld fatigue cracks. As well, the gas-steam combined cycle unit metal supervision content and inspection emphasis are studied and supplemented.
\end{abstract}

\section{Introduction}

Gas-steam combined cycle units have been developed rapidly in eriod, high thermal efficiency, fast start-up, and low emission pollution ${ }^{[1]}$. At the same time, most domestic gas-steam combined cycle units are in peak-shaving operation. The operation mode with frequent start-up and fast load changes greatly reduces the safety and reliability of the unit, which could cause hidden dangers of equipment, increas abnormal events, and even some influential and serious accidents.

At present, the metal supervision of gas-steam combined cycle units has not been carried out systematically and deeply for the lack of exclusive standard criterion. Although, it refers to the actual implementation of coal-fired units, the failure modes and supervision points of metal components are significantly different from those of coal-fired units. Hence, in this work, our work provided a reference for the development of the industry standard based on analyzation of the gassteam combined cycle units in recent years metal supervise application.

\section{Material selection}

China due to their short construction pThe material selection of gas-steam combined cycle units is quite different from that of coal-fired units of the same level. For large gas turbines, such as GE's 9FA, the hot end parts are made of nickel-cobalt-based austenitic alloy steel DS GTD-111, and the high-temperature oxidation-resistant coatings and anti-corrosion coating are used in the parts with high thermal load. The high temperature resistance and high strength characteristics of the material are more in line with the high-parameter and high-power requirements of the unit. Its strengthening methods, metallographic structure, high temperature performance, coating conditions, failure modes, and non-destructive testing methods are all different from ordinary heatresistant steels used in steam turbines ${ }^{[2]}$.

Due to the structure difference of waste heat boilers and steam turbines with coal-fired unit the selection of metal components and the failure modes of operation damage of combined cycle units are unique. Although the high-temperature end steel selected for the $9 \mathrm{~F}$ unit is same as the high-alloy steel used for the supercritical unit, the selection of other components should be improved, such as cylinders, shafts, rotors, blades, generator guard rings, steam drums etc.

\section{Typical failure cases}

\subsection{Blade break}

Statistics show that the problems of compressor blade shaking, blade root groove wear, and blade platform bulge in foreign units mostly occur after 16,000 hours of unit operation, while the shortest operating hours of domestic units with the same problem are only 4,900 hours ${ }^{[3]}$. According to the titeratures, more than ten domestic 9FA gas turbine compressor blade fracture events were introduced detailedly ${ }^{[4-6]}$ among which the high-cycle fatigue fracture is the principal one for 9FA gas turbine compressor blades due to the failure of a certain natural frequency of the blade to effectively avoid $\mathrm{Kn}$ and $\mathrm{zn}$ resonances. Furthermore, it shows that the compressor blade fractures accounts for up to $60 \%$, which could seriously threaten the safe operation of the unit and bring huge losses to the power plant.

In the actual operation process, in addition to the increase in daily abnormal incidents, the peak shaving unit may also experience some serious accidents and

*Corresponding author: yan-shi@chder.com 
equipment hidden dangers like .... These accidents and hidden dangers were found to be related to frequent peak shaving or daily shutdown ${ }^{[7]}$. Figure 1 and Figure 2 show the fracture morphology and damage degree of the compressor S1 of a certain S109FA gas-steam combined cycle unit respectively. The fracture morphology shows obvious high-cycle fatigue fracture. Through the analysis, the vibration of the shaft system near the critical speeds of 1,2 , and 3 gradually increases when the unit speeds up and and the compressor may have resonance when the speed changes every time the unit is started and stopped for the low resonance margin of the static blade of the compressor. Hence, after a long period of frequent daily start and stop operation, metal fatigue and dynamic and static friction would occur on the compressor blade under multiple resonances, and blade fracture is more likely to happen.

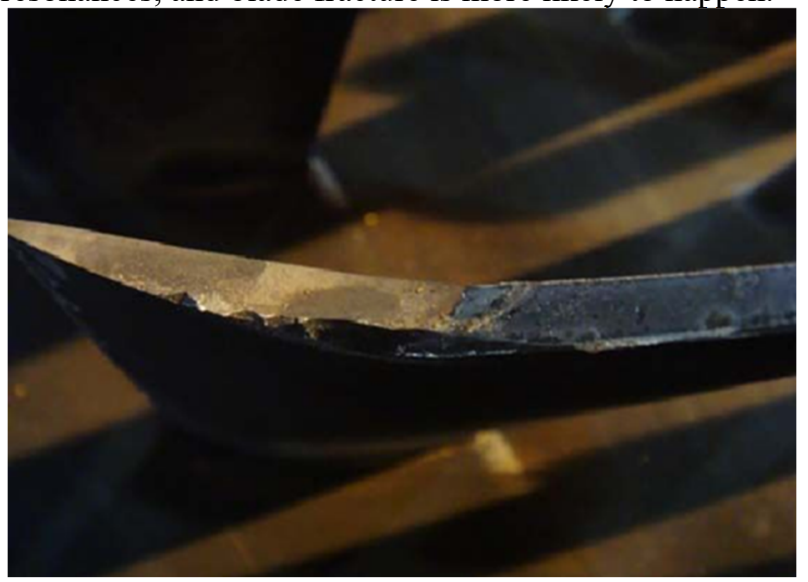

Fig1. Sectional appearance of compressor blade

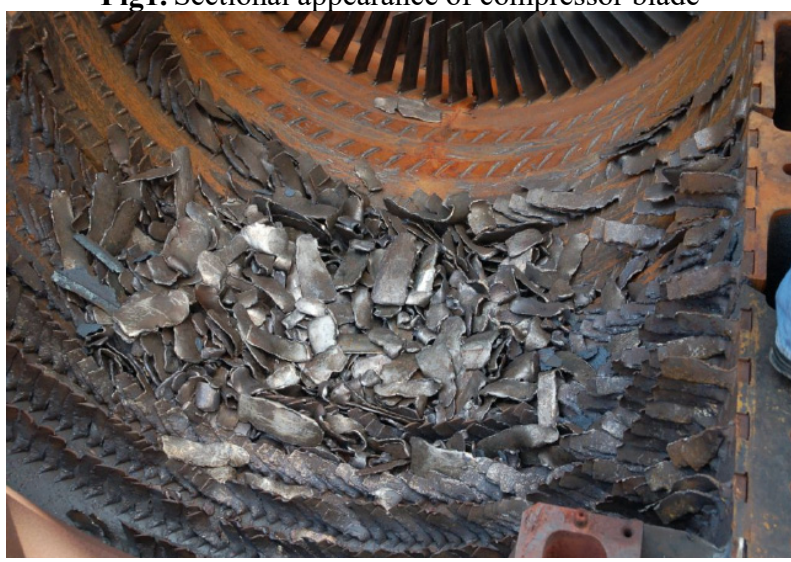

Fig2. Damage degree of compressor blade

\subsection{Fatigue crack in the body of main steam union valve}

A certain S109FA gas-steam combined cycle unit with a D10 standard steam turbine (GE) was selected to demonstrate the fatigue crack, and it is a single-shaft, three-pressure, reheat, two-cylinder, impulse condensing combined cycle steam turbine. By November 2018, the unit had been operated for a total of 42,528 hours and started and stopped 1,561 times. Cracks were found by endoscopy in the body of the high-pressure main steam union valve, which was made of GE brand B50A224B, equivalent to ASTM A356 Gr9 class, and the composition was 1 Cr1Mo V, namely ZG15Cr1Mo1V. As shown in Figure 3, multiple cracks were revealed by the color penetration test of the bottom joint surface of the highpressure main steam combined valve casing. The oxide scale around the crack was polished and then colored and penetrated again. It was clearly found that the crack surrounded the valve casing and the length reached about $4 / 5$ of the inner circumference of the valve casing. Further inspection showed that the crack starting point was located in the trap hole, as shown in Figure 4. Subsequently, the endoscope was used to detect the cracks inside the hydrophobic hole, and it was found that the cracks extended $4 \mathrm{~mm}$ along the hydrophobic hole.

The analysis shows that the drain flows backward into the valve from the trap of the valve seat and is deposited on the side of the trap. Generally, when the unit starts, steam flows through the valve seat, and the valve seat expands with heat. However, due to water accumulation in the trap side of the valve seat, the temperature rise on the trap side of the valve seat is obviously slower and the expansion is smaller than that on the sealing surface, resulting the tensile stress on the sealing surface. Conversely, when the unit is shut down, the sealing surface side shrinks relatively faster than the drainage hole side. Hence, the sealing surface side is subjected to additional compressive stress, and such alternate stress changes eventually lead to the cracking of the sealing surface. In all, the reasonable drainage pipe layout of the valve seat and timely drainage is of great significance for the long-time range stable operation. or combined cycle ${ }^{[8-}$ 9].

\subsection{Cracks in four pipes and headers}

A 9F gas-steam combined cycle generator set was put into production in 2013. It adopts a single-shaft combined cycle type and consists of a PG9351FA gas turbine, a dualcylinder dual-flow steam turbine with a D10 threepressure reheat system, a $390 \mathrm{H}$ hydrogen-cooled generator, and a three-pressure reheating system. During the maintenance period in April 2019, the metal supervisory inspection of the butt joint girth weld was carried out, and it was found that there was a pipe weld fusion line. The crack defect is about $150 \mathrm{~mm}$ long and the depth is about $10 \mathrm{~mm}$. Typical defects are shown in Figure 5 .

According to the survey data, the unit has been in operation for about 10,500 hours, andstarted and stopped 675 times, which frequently participates in peak-shaving variable load operation. In addition, the desuperheater often sprays water to adjust the high-pressure steam parameters. Frequent and drastic changes in temperature have brought great challenges to the service materials of the unit, causing multiple high-parameter steam leaks in the pipes, which has brought great harm to the safe and stable operation of the unit.

Figure 6 shows a SGT5-2000E cogeneration unit of a Siemens company. During operation, it was discovered that there was steam leakage in the pipe of the highpressure heat supply desuperheating and pressure reducer. The pipe material was $12 \mathrm{Cr} 1 \mathrm{MoVG}$ and the specification was $\Phi 273 \times 14 \mathrm{~mm}$. According to the shutdown inspection, circumferential cracks and through cracks were found in 
the pipe base material, and these cracks were located at the rear end of the nozzle head in the desuperheating water $150 \mathrm{~mm}$. It can be seen that, in view of the characteristics that gas units frequently start and stop to participate in peak adjustment operation, the metal inspection cycle of complex stressed parts of high-parameter pipelines, such as elbow weld, tee, temperature reducer, pipe base fillet weld and other key positions, should be shortened and special inspection of high-temperature and high-pressure steam pipelines should be carried out.

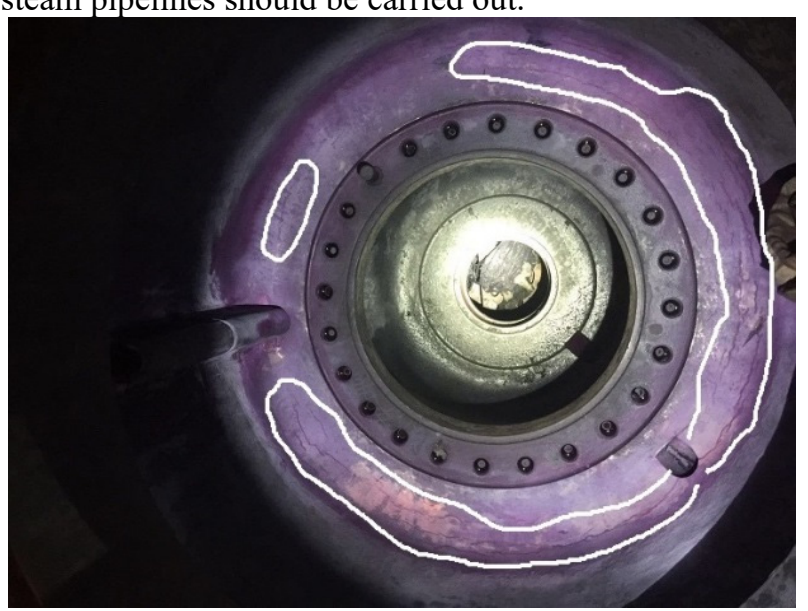

Fig3. Cracks at the bottom of the valve casing.

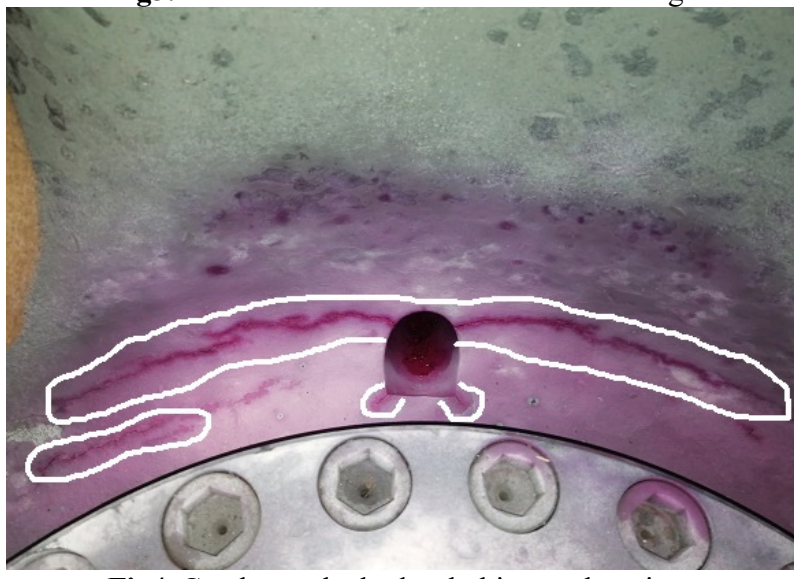

Fig4. Cracks on the hydrophobic port location.

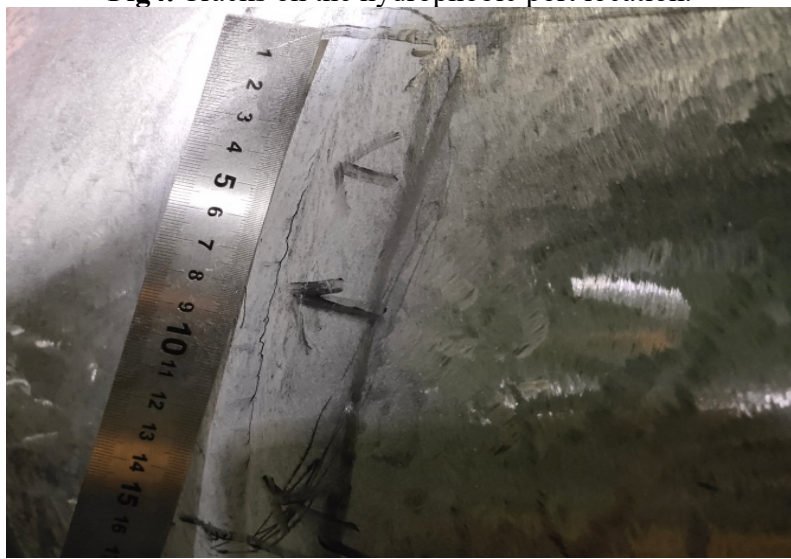

Fig5. Cracks on weld fusion line of the high voltage bypass desuperheater pipe.

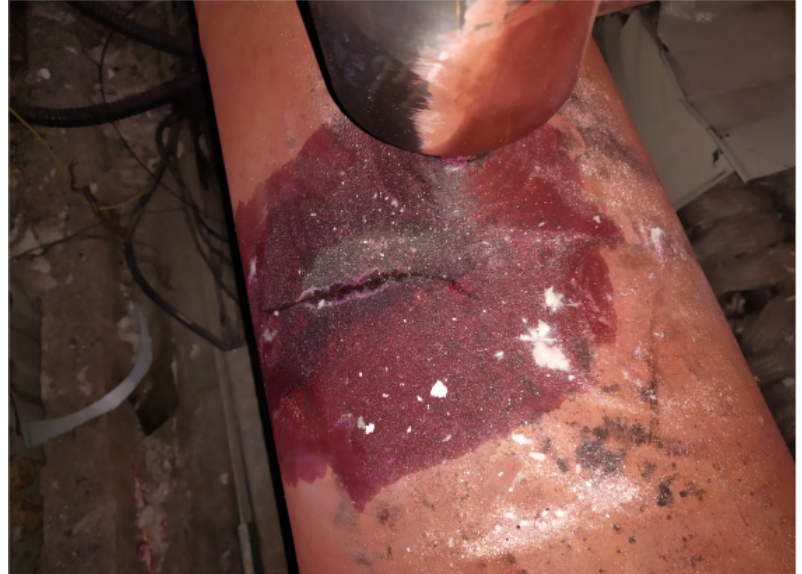

Fig6. Circumferential cracking of the base material of heating and desuperheating pressure reducer pipe.

\section{Metal supervision and inspection content and standards}

The aim of metal supervision is to detect and diagnose the in-service metal parts through various detection methods. Based on the supervisionthe relationship between performance changes and failure laws of metal parts could be establised, and then life analysis and evaluation of metal parts and equipment could also be conducted accordingly. So valid guidance could be provided for the unit operation and maintenance by metal supervision. The scope of metal supervision of gas-steam combined cycle units should cover high temperature, high pressure, high speed components of gas turbines, steam turbines, generators, waste heat boilers, pressure vessels and public systems and related metal components.

The objects of supervision include compressor moving stator blades, combustion chamber nozzles, cross-fire pipes, turbines and their cylinder blocks, guide sleeves, inlet adjustable guide vanes, alloy steel bolts, pressure pipes and valves, steam drums, heating surface pipes, header, drain pipeline, generator shaft and guard ring, generator fan blades, bearing bushes, partitions, cylinders, oil pipelines; gas turbine and steam turbine shafts, blades, braces, bearing bushes; heaters, deaeration pressure vessels, such as continuous blowdown expansion vessels and gas storage tanks, and steel frame structures.

The performance, material quality and welding quality of waste heat boilers, steam turbines, generators, pressure vessel components and ancillary equipment can be monitored in accordance with the minimum uncovered maintenance period provided by the manufacturer and the requirements of $\mathrm{DL} / \mathrm{T}$ 438-2016. Important supervised components such as the compressor, combustion chamber, turbine and its cylinder block of the gas turbine shall be inspected in accordance with the minimum uncovering maintenance cycle provided by the manufacturer, and shall be free of defects such as cracks, heavy skins, weld bead, and sand casting, and shall be inspected annually. At least one peephole inspection should be performed, which showed in Table 1. Other parts, such as steel wire of intake safety separation net, gear tooth of load gear box and auxiliary gear box, should be inspected macro inspection and surface inspection every time, which are repaired to 
check the wear condition and confirm if there exists deformation or fracture.

Table1. Supervision and inspection of important supervised components

\begin{tabular}{|c|c|c|c|c|}
\hline Device name & Part name & Project content & Standard requirement & Inspection cycle \\
\hline Compressor & $\begin{array}{l}\text { Rotor, guide } \\
\text { vane, moving } \\
\text { vane }\end{array}$ & $\begin{array}{l}\text { Macro inspection, non-destructive testing } \\
\text { if necessary }\end{array}$ & $\begin{array}{l}\text { No deformation, corrosion pits, } \\
\text { impact craters }\end{array}$ & $\begin{array}{c}\text { Minimum } \\
\text { uncovering } \\
\text { overhaul period }\end{array}$ \\
\hline \multirow[t]{2}{*}{$\begin{array}{l}\text { Combustion } \\
\text { chamber }\end{array}$} & $\begin{array}{l}\text { Flame tube, } \\
\text { continuous flame } \\
\text { tube, transition } \\
\text { section }\end{array}$ & $\begin{array}{c}\text { Macro inspection, wall thickness } \\
\text { inspection, ultrasonic surface wave } \\
\text { inspection and fluorescence penetration } \\
\text { inspection if necessary }\end{array}$ & $\begin{array}{l}\text { No cracks, wear, corrosion, etc., no } \\
\text { peeling, overheating, bulging, burn } \\
\text { through, cracks caused by thermal } \\
\text { fatigue, high temperature oxidation } \\
\text { wear and corrosion wear of the } \\
\text { thermal insulation coating }\end{array}$ & $\begin{array}{l}\text { Minimum } \\
\text { uncovering } \\
\text { overhaul period }\end{array}$ \\
\hline & $\begin{array}{l}\text { Moving blades, } \\
\text { stationary blades }\end{array}$ & $\begin{array}{l}\text { Macro inspection, non-destructive testing } \\
\text { if necessary }\end{array}$ & $\begin{array}{l}\text { No wear, cracks, corrosion pits, } \\
\text { impact craters, wear or cracks }\end{array}$ & $\begin{array}{c}\text { Minimum } \\
\text { uncovering } \\
\text { overhaul period }\end{array}$ \\
\hline \multirow[t]{2}{*}{ Turbine } & $\begin{array}{l}\text { Nozzle, partition, } \\
\text { double ring }\end{array}$ & $\begin{array}{l}\text { Macroscopic inspection, non-destructive } \\
\text { testing if necessary. If the amount of wear } \\
\text { is large, the coating should be re-coated } \\
\text { according to the equivalent operating time } \\
\text { and repair standard manual provided by } \\
\text { the manufacturer; if necessary, the nozzle } \\
\text { should be taken out for hardness and } \\
\text { metallographic testing. The cycle should } \\
\text { not exceed } 25,000 . \mathrm{h}\end{array}$ & $\begin{array}{l}\text { No corrosion pits, impact craters, } \\
\text { wear, cracks }\end{array}$ & $\begin{array}{l}\text { Minimum } \\
\text { uncovering } \\
\text { overhaul period }\end{array}$ \\
\hline & $\begin{array}{l}\text { Wheel shaft, } \\
\text { impeller }\end{array}$ & $\begin{array}{l}\text { Macroscopic inspection, if necessary, } \\
\text { surface penetration inspection; if } \\
\text { necessary, endoscopic, eddy current or } \\
\text { ultrasonic inspection of the rotor center } \\
\text { hole (if any), the cycle should not exceed } \\
50,000 \mathrm{~h} \text {; ultrasonic inspection of the } \\
\text { impeller keyway; hardness, } \\
\text { Metallographic inspection }\end{array}$ & $\begin{array}{l}\text { No corrosion pits, impact craters, } \\
\text { abrasion, cracks, no abnormal } \\
\text { hardness, no abnormal } \\
\text { metallographic structure }\end{array}$ & $\begin{array}{c}\text { Minimum } \\
\text { uncovering } \\
\text { overhaul period }\end{array}$ \\
\hline Cylinder & / & $\begin{array}{l}\text { Macro inspection of the compressor } \\
\text { cylinder block, combustion chamber } \\
\text { cylinder block and turbine cylinder block }\end{array}$ & $\begin{array}{l}\text { No defects such as cracks, heavy } \\
\text { skins, weld bumps, cast sand, etc. }\end{array}$ & $\begin{array}{l}\text { Minimum } \\
\text { uncovering } \\
\text { overhaul period }\end{array}$ \\
\hline
\end{tabular}

\section{Conclusions}

The frequent start-stop operation mode of domestic gassteam combined cycle units accelerates the occurrence of defects such as fatigue, cracks, and structural deterioration of monitored metal components. Combined with the analysis of failure cases such as fatigue fracture of compressor blades, valve body fatigue cracks of main steam combined valve, fatigue cracking of pipelines and pressure vessel welds, this paper summarizes the diagnosis content \& standards and the supervision \& inspection of the important supervised metal parts of gassteam combined cycle units.

It is suggested to combine with the application of metal supervision of domestic gas-steam combined cycle unit, gradually master the performance change and failure rule of metal parts, improve relevant standards, and predict the defects and hidden dangers of supervised metal parts in advance to avoid the social property loss caused by major equipment abnormal events.

\section{References}

1. P.Chen, Z.Y.Liu and M.B.Gan, Metal Technology Supervision-Guarantee of Safe and Economical Operation of Gas Turbine Power Plant Units, Gas turbine technology, 2003, vol.16, pp.132-133.

2. L.P.Chen and G.T.Meng, Application of Metal Supervision Techniques in Gas-Steam Combined Cycle Units, Power Equipment, 2006, vol.17, pp.320-
325.

3. T.Zhang and Y.S.Wu, Fracture Failureand Prevention Measures of 9FA Gas Turbine Compressor Vanes, Gas turbine technology, 2013, vol.26, pp.48-52.

4. J.F.Xiao, Y.Zhao and S.T.Liu, etc.,Analysis of the Causes of Fracture Failure of S1 Stage Blades of 9FA Gas Turbine Compressor-Proceedings of the 2010 Academic Symposium of the Turbine Professional Committee of the Chinese Society of Power Engineering, Turbine Professional Committee of the Chinese Society of Power Engineering, Shanghai, 2010.

5. L.Q.Wang, F.Z.Zhou and J.H.Wang, Analysis of the reasons for the fracture of S1 blade of 9FA+e gas turbine compressor, Power System Engineering, 2011, vol.27, pp.69-70.

6. J.Q.Han, Tpical Faults and Handling Approachs of S209FA Gas-Steam Combined Cycle Unit, Gas turbine technology, 2013, vol.26, pp.52-56.

7. G.Tan, Daily starting and stopping effect on 9FA Combined-Cycle Unit, Master's degree thesis of South China University of Technology, Guangzhou, 2015.

8. Y.N.Ding, and W.X.Zhu, 9FA gas turbine/turbine main steam cut-off and control valve failure, Maintenance and Repair, 2010, vol.4, pp.18-19.

9. X.D.Yao, Failure analysis and treatment of intermediate pressure steam bypass valve of M701F gas-steam combined cycle unit, Ventilation and Air Conditioning Installation, 2019, vol.8, pp.24-25. 